Jurnal Hukum Mimbar Justitia

Fakultas Hukum Universitas Suryakancana

Vol. 4 No. 1 - Juni 2018, hlm. 22-42

ISSN: 2477-5681 (Cetak), ISSN: 2580-0906 (Online)

Open Access at: https://jurnal.unsur.ac.id/jmj

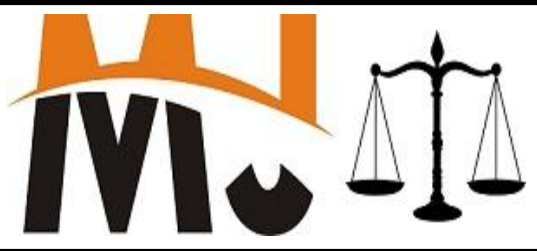

\title{
KEABSAHAN SERTIFIKAT JAMINAN FIDUSIA ATAS BARANG MILIK PIHAK KETIGA YANG DIJAMINKAN SECARA MELAWAN HUKUM
}

\author{
Anita Kamilah \\ Universitas Suryakancana \\ E.mail : anita.kamilah@yahoo.co.id
}

Masuk: Maret 2018

Penerimaan: April 2018

Publikasi: Juni 2018

\begin{abstract}
ABSTRAK
Kesinambungan pembangunan nasional merupakan upaya peningkatan kehidupan masyarakat yang didukung melalui pemberian fasilitas kredit atau pinjaman, sebagai penyediaan uang atau tagihan yang dapat dipersamakan dengan itu berdasarkan perjanjian pinjam meminjam yang pengembaliannya dilakukan pada suatu jangka waktu yang akan datang. Guna memberikan perlindungan dan kepastian terhadap kreditur dalam mendapatkan pengembalian kreditnya, pemerintah mengesahkan UndangUndang No. 42 Tahun 1999 Tentang Jaminan Fidusia yang memberikan hak kepada kreditur melalui sertifikat fidusia sebagai jaminan kebendaan yang diserahkan atas dasar kepercayaan, dimana pemilik jaminan masih dapat mempergunakan bendanya untuk kegiatan ekonomi. Kemudahan tersebut, seringkali disalahgunakan debitur yang beritikad tidak baik salah satunya melalui penjaminan objek fidusia milik pihak ketiga secara melawan hukum sehingga merugikan kreditur karena mengakibatkan tidak sahnya jaminan fidusia sehingga kreditur tidak lagi memiliki hak preferent untuk mendapatkan pembayaran secara didahulukan jika debitur wanprestasi dalam memenuhi kewajiban pembayaran kreditnya. Selain itu, merugikan pemilik barang yang kepemilikan bendanya dijadikan objek jaminan fidusia. Perlindungan hukum bagi pemilik barang akibat penjaminan objek fidusia secara melawan hukum tersebut dapat melakukan penuntutan ganti rugi serta meminta dihilangkannya gangguan-gangguan kenikmatan atas hak kebendaannya.
\end{abstract}

Kata Kunci: Kredit, Sertifikat Fidusia, Melawan Hukum, Ganti Rugi.

\section{ABSTRACT}

Sustainability of national development is the increase in the life of the community effort that is supported through the granting of credit facilities or loans, as the provision of money or bills that can be equated with that loan agreement borrow the returns are made on a period of time to come. In order to provide protection and reassurance against creditors in obtaining her credit refund, the Government ratified the Act No. 42 Year 1999 About the Fiduciary Guarantee gives the right to the lender through fiduciary certificates as material warranties that are submitted on the basis of trust, where the owner can still use his guarantee for economic activities. The ease, often 
abused the debtor not good intentioned one through the securing of objects belonging to third parties fiduciary are against the law to the detriment of creditors because it resulted in no fiduciary guarantee legitimately so the lender no longer has the right to obtain payment preferent precedence if the debtor tort in fulfilling the obligation payment of his credit. In addition, the owners of goods that harms his ownership was made the object of a fiduciary guarantee. Legal protection for owners of goods due to the securing of objects that are against the law of fiduciary relationships can do the prosecution indemnity as well as requesting removal of the disturbances a pleasure over the right material.

Keywords: Fiduciary Certificates, Credit, Against The Law, Torts.

\section{PENDAHULUAN}

Pembangunan ekonomi, sebagai bagian dari pembangunan nasional memiliki peran besar dalam mencapai masyarakat yang adil dan makmur berdasarkan Pancasila dan UUD 1945 yang pelaksanaannya perlu dukungan pendanaan yang besar melalui kegiatan pinjam meminjam atau kredit. ${ }^{1}$ Mengingat dana yang dipinjamkan tersebut akan dikembalikan pada suatu jangka waktu yang akan datang, maka guna menjamin pengembaliannya serta menghindari risiko kemungkinan terjadinya pinjaman yang macet, pada tanggal 30 September 1999 pemerintah mengesahkan Undang-Undang No. 42 Tahun 1999 Tentang Jaminan Fidusia. ${ }^{2}$

1 Rindia Fanny Kusumaningtyas, 2016, Perkembangan Hukum Jaminan Fidusia Berkaitan dengan Hak Cipta Sebagai Objek Jaminan Fidusia, Jurnal Pandecta, Volume. 11, Nomor. 1, Juni, hlm. 97.

2 Nur Adi Kumaladewi, 2015, Eksekusi Kendaraan Bermotor Sebagai Jaminan Fidusia yang Berada Pada Pihak Ketiga,
Jaminan Fidusia telah digunakan di Indonesia sejak zaman penjajahan Belanda sebagai suatu bentuk jaminan yang lahir dari yurisprudensi, selain pembebanannya dianggap sederhana, mudah, dan cepat, ${ }^{3}$ juga pemberi fidusia masih dapat menguasai serta menggunakan benda yang dijaminkan sehingga tidak menganggu kegiatan ekonomi pemberi fidusia sebagai peminjam/penjamin. ${ }^{4}$ Fakta empiris menunjukkan kemudahan pembebanan fidusia yang diatur dalam UndangUndang No. 42 Tahun 1999 seringkali

Jurnal Repertorium, Volume. 2, Nomor. 2, Edisi Juli - Desember, hlm. 61.

3 Muladi, 2009, Pentingnya Lembaga Jaminan Fidusia Dalam Meningkatkan Pembangunan Ekonomi Nasional, Makalah Seminar Nasional Problematika Dalam Pelaksanaan Jaminan Fidusia di Indonesia : Upaya Menuju Kepastian Hukum, Fakultas Hukum Universitas Semarang, Semarang, hlm. 3.

4 Prihati Yuniarlin, 2012, Penerapan Unsurunsur Perbuatan Melawan Hukum Terhadap Kreditur Yang Tidak Mendaftarkan Jaminan Fidusia, Jurnal Media Hukum, Volume 19, No. 1, Edisi Juni, hlm. 2. 
Anita Kamilah

Jurnal Hukum Mimbar Justitia

Vol. 4 No. 1 - Juni 2018

disalahgunakan oleh pemberi fidusia yang memiliki itikad buruk untuk keuntungan pribadinya, seperti pada kasus yang dihadapi PT. BFI Cabang Palembang melalui Pembiayaan Konsumen No. 4051301223 tanggal 06 Maret 2014 atas nama Billy Warda Putra, yang menjaminkan 1 (satu) unit R4 Suzuki Ertiga GX 1.4 MT, warna putih metalik, tahun 2012, No. Pol.: BG 1322RT, Nomor mesin: K14BT1004022 dan Nomor rangka: MHYKZE81SCJ103984, dengan sertifikat fidusia No W6.00069003. AH.051.01 tanggal 27 Maret 2014. Pinjaman mengalami kemacetan karena sejak angsuran ke 19, Billy Warda Putra tidak melaksanakan kewajibannya sehingga merugikan PT. BFI Cabang Palembang, dan atas kelalaian pembayaran pinjaman tersebut, PT. BFI Cabang Palembang telah memberikan peringatan, sebagaimana telah diatur secara khusus dari perjanjian kredit maupun perjanjian fidusia yang dibuat para pihak, maupun sebagaimana diatur dalam ketentuan Pasal 1238 KUH Perdata tentang penetapan lalai "ingebrekkestelling" sebagai ketentuan umumnya, namun debitur tetap melalaikan kewajibannya.
Berlandasarkan sertifikat fidusia No W6.00069003. AH.051.01 tanggal 27 Maret 2014, PT. BFI Cabang Palembang dapat menggunakan haknya untuk melakukan eksekusi atas jaminan kendaraan bermotor yang dijaminkan Billy Warda Putra, tetapi ketika akan dieksekusi, kendaraan yang menjadi objek jaminan fidusia tersebut berada di tangan pihak ketiga yang diketahui sebagai pemiliknya, yang telah dijaminkan pemberi fidusia tanpa seizin dan sepengetahuan pemilik barang. Kasus yang dihadapi PT. BFI Cabang Palembang tersebut menimbulkan suatu persoalan yang tidak sederhana baik bagi pemberi PT. PT. BFI Cabang Palembang sebagai penerima fidusia, maupun bagi pihak ketiga yang hak kepemilikannya dijadikan jaminan pihak lain tanpa izin tertulis darinya. Guna mengkajinya secara mendalam maka diidentifikasi hal-hal sebagai berikut: (1) Bagaimanakah keabsahan sertifikat jaminan fidusia atas barang milik pihak ketiga yang penjaminannya dilakukan secara melawan hukum?; dan (2) Bagaimanakah perlindungan hukum pemilik hak atas benda akibat penjaminan fidusia secara melawan hukum?. 


\section{METODE PENELITIAN}

Metode pendekatan yang digunakan dalam penelitian ini yuridis normatif yaitu mempelajari dan mengkaji asas-asas hukum khususnya kaidah-kaidah hukum positif yang memiliki keterkaitan dengan kasus yang dikaji. ${ }^{5}$ Spesifikasi penelitian desktiptif analisis untuk memberikan gambaran umum yang menyeluruh dan sistematis mengenai keabsahan sertifikat jaminan fidusia atas barang milik pihak ketiga yang dijaminkan secara melawan hukum. Gambaran umum tersebut dianalisis dengan bertitik tolak pada peraturan perundang-undangan, pendapat para ahli, yang bertujuan untuk mencari dan mendapatkan jawaban atas pokok masalah yang akan dibahas lebih lanjut. Jenis dan sumber data yang mendukung penelitian ini yaitu data sekunder yang terdiri dari bahan hukum primer diantaranya Undang-Undang No. 42 Tahun 1999 Tentang Jaminan Fidusia, Kitab Undang-Undang Hukum Perdata Buku II tentang Benda (Van Zaken) dan Buku III tentang Perikatan (Van
Verbintenissen), serta bahan hukum sekunder yang bersifat membantu atau menunjang bahan hukum primer seperti buku-buku, jurnal dan dokumendokumen dalam hal ini Laporan Polisi : LPB/133/II/2016/SPKT, tanggal 22 Februari 2016. Analisis data dilakukan secara Content Analysis yang integratif dan secara konseptual diarahkan untuk menemukan, mengidentifikasi, mengolah, dan menganalisis bahan hukum-bahan hukum tersebut untuk memahami suatu persoalan tertentu, sehingga mendapatkan jawabannya.

III. HASIL PENELITIAN DAN ANALISIS

\section{A. Keabsahan Sertifikat Jaminan Fidusia Atas Barang Milik Pihak Ketiga Yang Penjaminannya Dilakukan Secara Melawan Hukum.}

Lembaga jaminan fidusia yang dalam hukum Romawi dikenal dengan fiducia cum creditore contracta sudah sangat tua digunakan masyarakat Romawi, yang kemudian diadopsi dalam hukum Belanda melalui yurisprudensi putusan Hoge Raad tertanggal 25 Januari 1929 yang dikenal

5 Ronny Hanitijo Soemitro, 1990, Metodologi Penelitian Hukum Dan Jurimetri, Ghalia Indonesia, Jakarta, hlm. 22. 
Anita Kamilah

Jurnal Hukum Mimbar Justitia

Vol. 4 No. 1 - Juni 2018

dengan Bierbrowerij $_{\text {Arrest. }}{ }^{6} \quad$ Latar

belakang lahirnya fidusia, karena

terkendala oleh ketentuan gadai

sebagaimana diatur dalam Pasal 1152

KUH Perdata yang menyebutkan bahwa

syarat sahnya gadai, benda atau barang yang digadaikan harus diserahkan kepada pemegang gadai, padahal justru benda tersebut penting bagi kegiatan pemberi gadai, sehingga kondisi tersebut menghambat bagi perkembangan ekonomi masyarakat. ${ }^{7}$

Undang-Undang No. 42 Tahun 1999 Tentang Jaminan Fidusia, diharapkan selain dapat menampung kebutuhan masyarakat juga dapat memberikan kepastian hukum kepada para pihak yang berkepentingan, karena sesuai dengan ketentuan Pasal 1 ayat (1) bahwa Fidusia adalah pengalihan hak kepemilikan suatu benda yang dilakukan atas dasar kepercayaan, dimana benda yang hak kepemilikannya dialihkan tersebut tetap dalam

6 Nur Amin Solikhah, 2015, Problematika Hukum Undang-Undang No. 42 Tahun 1999 Tentang Jaminan Fidusia Terkait Dengan Peraturan Menteri Keuangan Republik Indonesia No. 130/PMK.010/2012, Jurnal Repertorium, Edisi 3, Januari - Juni, hlm. 8.

7 Rindia Fanny Kusumaningtyas, 2016, Perkembangan Hukum Jaminan Fidusia ..., Op.Cit., hlm. 99.

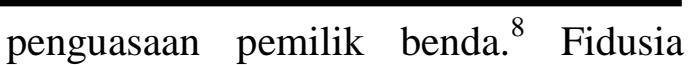
merupakan lembaga jaminan kebendaan (zakelijk zekerheid, security right in rem), berupa penyediaan suatu bagian dari kekayaan seseorang, si pemberi jaminan, dan menyediakannya guna pemenuhan (pembayaran) kewajiban (utang) seorang debitur. ${ }^{9}$

Objek benda jaminan fidusia sesuai Pasal 1 angka 2 Undang-Undang No. 42 Tahun 1999 adalah benda bergerak baik yang berwujud maupun yang tidak berwujud dan benda tidak bergerak khususnya bangunan yang tidak dapat dibebani hak tanggungan sebagaimana dimaksud dalam Undangundang Nomor 4 Tahun 1996 Tentang Hak Tanggungan sebagai agunan bagi pelunasan hutang tertentu yang memberikan kedudukan utama terhadap kreditur lain sebagaimana diatur dalam

8 Winda Pebrianti, 2012, Tinjauan Hukum Atas Eksekusi Obyek Jaminan Fidusia Melalui Parate Eksekusi Apabila Obyek Jaminan Beralih Kepada Pihak Ketiga atau Musnah, Jurnal Supremasi Hukum, Volume. 21, Nomor. 1, Edisi Januari, hlm. 83.

9 Dilva Muzdaliva Sawotong, 2014, Jaminan Kebendaan Pada PT. Pegadaian Terhadap Barang Yang Digadaikan, Jurnal Lex Privatum, Volume. 2, Nomor. 2, Edisi Januari-Maret, hlm. 39, dan Nur Adi Kumaladewi, 2015, Eksekusi Kendaraan Bermotor Sebagai Jaminan Fidusia Yang Berada Pada Pihak Ketiga, Jurnal Repertorium, Volume. 2, Nomor. 2, Edisi Juli-Desember, hlm. 64. 
Anita Kamilah

Jurnal Hukum Mimbar Justitia

Vol. 4 No. 1 - Juni 2018

Pasal 1 ayat (2) dan Pasal 27 ayat (1) yang kemudian dikenal dengan prinsip preferent.

Selain menganut prinsip preferent, jaminan fidusia juga memiliki ciri-ciri sebagai berikut: (1) Memenuhi asas spesialitas dan publisitas, bahwa benda yang dibebani dengan jaminan fidusia wajib didaftarkan (Pasal 11 ayat (1); (2) Selalu mengikuti objeknya dalam tangan siapapun benda tersebut berada (Pasal 20); dan (3) Mudah serta pasti pelaksanaan eksekusinya (Pasal 15 ayat (2)). ${ }^{10}$

Guna mendapatkan kedudukan preferent tersebut, pembebanan benda dengan jaminan fidusia tidak cukup dibuat dengan akta notaris saja, tetapi sesuai Pasal 11 ayat (1) UndangUndang Fidusia, mewajibkan dilakukan pendaftaran di Kantor Pendaftaran Fidusia, dan hal inipun telah dilakukan PT. BFI Cabang Palembang dengan diterimanya sertifikat fidusia No. Nomor: W6.00069003.AH.051.01 Tahun 2014 tanggal 27 Maret 2014, yang di dalamnya mencantumkan kata-

10 Clara Lina Amanda Sumeisey, 2014, Eksekusi Benda Jaminan Yang Dibebani Hak Tanggungan Ketika Debitur Pailit, Jurnal Lex et Societatis, Volume II, No.9, Edisi Desember, hlm. 7. kata

"DEMI

KEADILAN

BERDASARKAN

KETUHANAN

YANG MAHA ESA", yang mengandung titel eksekutorial dimana sertifikat jaminan fidusia tersebut mempunyai kekuatan yang sama dengan suatu keputusan pengadilan yang telah memperoleh kekuatan hukum yang tetap. $^{11}$

Berdasarkan sertifikat jaminan fidusia tersebut, sesuai Pasal 15 ayat (3) Undang-Undang No. 42 Tahun 1999 maka atas kelalaian Billy Warda Putra sebagai pemberi fidusia, PT. BFI Cabang Palembang mempunyai hak untuk menjual benda yang menjadi objek jaminan fidusia atas kekuasaannya sendiri serta mengambil pelunasan dari hasil penjualan objek jaminan tersebut untuk melunasi hutang-hutangnya. Guna melaksanakan hak tersebut, PT. BFI Cabang Palembang melakukan pemeriksaan terhadap kendaraan yang dijaminkan pemberi fidusia, namun benda yang menjadi objek jaminan fidusia tersebut berada pada penguasaan pihak ketiga

11 Debora R.N.N. Manurung, 2015, Perlindungan Hukum Debitur Terhadap Parate Eksekusi Obyek Jaminan Fidusia, Jurnal Ilmu Hukum Legal Opinion, Volume. 3, Nomor. 2, hlm. 4. 
Anita Kamilah

Jurnal Hukum Mimbar Justitia

Vol. 4 No. 1 - Juni 2018

yang kemudian diketahui bahwa kendaraan tersebut merupakan milik Alimayer yang pernah dipinjam oleh Billy Warda Putra, tetapi kemudian tanpa seizin dan sepengetahuannya, Billy Warda Putra secara melawan hukum menjaminkan kendaraan tersebut pada PT. BFI Cabang Palembang. ${ }^{12}$ Kondisi tersebut menjadi salah satu faktor penghambat bagi PT. BFI Cabang Palembang untuk dapat melakukan eksekusi jaminan fidusia, karena dari sudut pandang yuridis pengikatan jaminan fidusianya dilakukan pemberi fidusia secara tidak sah sebagaimana diatur dalam Pasal 1320 KUH Perdata serta dilakukan secara melawan hukum (Onrechtmatige daad) sebagaimana diatur dalam Pasal 1365 KUH Perdata. Sesuai Pasal 1320 KUH Perdata, untuk sahnya perjanjian jaminan fidusia harus memenuhi 4 (empat) syarat yaitu: (1) sepakat mereka yang mengikatkan dirinya; (2) cakap untuk membuat suatu perjanjian; (3)

12 Laporan Hasil Penyelidikan Kepolisian Negara Repubik Indonesia Daerah Sumatera Selatan Direktorat Reserse Kriminal Khusus No. LHP/XII/2016/Subdit II/Ditreskrimus, Desember 2016. mengenai suatu hal tertentu; dan (4) suatu sebab yang halal. ${ }^{13}$

Mengkaji pada ketentuan Pasal 1320 KUH Perdata, penjaminan kendaran tersebut tidak memenuhi syarat kesepakatan, karena di dalamnya terdapat unsur kecacatan berupa rangkaian tipu muslihat yang dilakukan Billy Warda Putra dimana seolah-olah benda/barang yang dijadikan objek jaminan tersebut miliknya sehingga menimbulkan kepercayaan dari PT. BFI Cabang Palembang untuk menerima kendaraan tersebut sebagai objek jaminan atas kredit atau pembiayaan yang telah diberikannya. Berkaitan dengan syarat kedua yaitu kecakapan untuk melakukan perbuatan hukum, bahwa meskipun sebagai subjek hukum Billy Warda Putra memenuhi ketentuan Pasal 1330 KUH Perdata yaitu sudah dewasa dan memiliki kecakapan untuk melakukan perbuatan hukum, tetapi yang bersangkutan tidak memiliki kewenangan untuk mengalihkan benda/barang orang lain tanpa seizin dan sepengetahuan pemiliknya. Syarat

13 Miftah Idris, 2015, Perjanjian Kredit Perbankan Konvensional Dan Akad Pembiayaan Perbankan Syariah: Suatu Tinjauan Deskriptif Dalam Hukum Di Indonesia, Jurnal Komunikasi Hukum, Volume. 1, Nomor. 1, Februari, hIm. 34. 
Anita Kamilah

Jurnal Hukum Mimbar Justitia

Vol. 4 No. 1 - Juni 2018

ketiga mengenai barang yang menjadi objek perjanjian sudah terpenuhi yaitu suatu barang tertentu, dimana barang yang merupakan objek jaminan fidusia tersebut adalah 1 (satu) unit R4 Suzuki Ertiga GX 1.4 MT, warna putih metalik, tahun 2012, No. Pol. : BG 1322RT, Nomor mesin: K14BT1004022 dan Nomor rangka

MHYKZE81SCJ103984. Berbeda jika dikaji dari sudut pandang sifat dan hakikatnya, barang atau kendaraan tersebut tidak dapat dijadikan objek jaminan fidusia, karena penjaminannya dilakukan oleh orang yang tidak berwenang, ${ }^{14}$ dan hak ini memiliki keterkaitan dengan syarat keempat tentang kausa perjanjian, maka penjaminannya bertentangan dengan undang-undang khususnya mengenai kepemilikan suatu benda sebagaimana diatur dalam Buku II KUH Perdata tentang Benda “Van Zaken”, Pasal 499 sampai dengan Pasal 1234, dimana salah satu asasnya yaitu Nemoplus jurist bahwa seseorang tidak dapat

14 Syamsul Anwar, 2007, Hukum Perjanjian Syariah, Grafindo Persada, Jakarta, hlm. 205. mengalihkan sesuatu hak melebihi apa yang menjadi haknya. ${ }^{15}$

Syarat pertama dan kedua di atas merupakan syarat subjektif yang berarti apabila suatu perikatan atau perjanjian tidak memenuhi kedua syarat tersebut, perikatan atau perjanjian tersebut dapat dibatalkan. Sebaliknya syarat ketiga dan keempat di atas merupakan syarat objektif yang berarti apabila suatu perikatan atau perjanjian tidak memenuhi syarat objektif tersebut, perikatan atau perjanjian tersebut batal demi hukum dan sejak semula dianggap tidak terjadi perjanjian. Oleh karena itu, maksud para pihak untuk melakukan perjanjian jaminan fidusia itu dianggap tidak pernah ada. ${ }^{16}$

Selain itu, mengkaji ketentuan Pasal 1365 KUH Perdata, tindakan Billy Warda Putra menjaminkan kendaran milik Alimayer merupakan perbuatan yang melawan hukum (Onrechtmatige daad) yaitu: "Tiap perbuatan melawan

15 Muhamad Rizky Djangkarang, 2013, Aspek Hukum Pengalihan Hak Tagihan Melalui Cessie, Jurnal Lex Privatum, Volume. 1, Nomor. 5, November, hlm. 79. Muhamad Djumhana, 2008, Asas-Asas Hukum Perbankan, Citra Aditya Bakti, Bandung, hlm. 242, dan Agus Yudha Hernoko, 2010, Hukum Perjanjian: Asas Proporsionalitas dalam Kontrak Komersial, Kencana Prenada Media Group, Jakarta, hlm. 160-161. 
Anita Kamilah

Jurnal Hukum Mimbar Justitia

Vol. 4 No. 1 - Juni 2018

hukum yang membawa kerugian kepada orang lain, mewajibkan orang karena salahnya menerbitkan kerugian itu, mengganti kerugian tersebut". ${ }^{17}$ Oleh karena titel pengikatan objek jaminan fidusia itu tidak memiliki alas hak yang sah, akibat hukumnya keabsahan perjanjian jaminan fidusia maupun sertifikat fidusianya, sebagaimana disampaikan Subekti menjadi batal demi hukum. Hal ini selaras dengan ketentuan Pasal 1381 KUH Perdata tentang hapusnya perikatan khususnya tentang kebatalan dan pembatalan perjanjian sebagaimana diatur dalam Pasal 1446 sampai dengan Pasal 1456 KUH Perdata. ${ }^{18}$

Pertanyaannya apakah dengan tidak sahnya perjanjian penjaminan fidusia tersebut, PT. BFI Cabang Palembang sebagai penerima fidusia tidak mendapatkan perlindungan hukum jaminan akibat kelalaian debitur dalam membayar kredit. Mengkaji Pasal 4 Undang-Undang No. 42 Tahun 1999, bahwa jaminan fidusia

17 Munir Fuady, 2013, Perbuatan Melawan Hukum Pendekatan Kontemporer, Citra Aditya Bakti, Bandung, hlm. 134.

18 Ficky Nento, 2016, Tinjauan Hukum Hapusnya Perikatan Jual Beli Barang Menurut Kitab Undang-Undang Hukum Perdata, Jurnal Lex Crimen, Volume. 5, Nomor. 6, Agustus, hlm. 75. merupakan perjanjian ikutan (acessoir) dari suatu perjanjian pokok. ${ }^{19}$ Oleh karena itu, tidak sahnya perjanjian jaminan fidusia maupun sertifikat jaminan fidusia sebagai perjanjian acessoir tidak berarti perjanjian pinjam memimjam sebagai perjanjian pokoknya batal, karena ada dan berakhirnya tidak tergantung pada perjanjian jaminan fidusia sebagai perjanjian ikutannya. Namun demikian, dengan tidak sahnya pengikatan perjanjian jaminan fidusia tersebut, memiliki akibat PT. BFI Cabang Palembang sebagai pemberi pinjaman tidak mendapatkan jaminan kebendaan yang bersifat preferent artinya tidak memiliki sifat mendahului untuk dilakukan pembayaran hutanghutangnya jika debitur wanprestasi, atau lalai.

Namun demikian, mengadopsi konsep-konsep umum hukum jaminan nasional, maka jika Billy Warda Putra sebagai debitur wanprestasi tidak

19 Dian Pertiwi, 2012, Perlindungan Pemegang Hak Tanggungan Yang Objeknya Dikuasai Pihak Ketiga Berdasarkan Perjanjian Sewa Menyewa, Caliptra Jurnal IImiah Mahasiswa Universitas Surabaya, Volume. 19, No. 1, Juni, hlm. 6, dan Atik Indriyani, 2006, Aspek Hukum Personal Guaranty, Jurnal Hukum PRIORIS, Volume. 1, Nomor. 1, September, hlm. 28. 
Anita Kamilah

Jurnal Hukum Mimbar Justitia

Vol. 4 No. 1 - Juni 2018

memenuhi kewajiban melakukan pembayaran, PT. BFI Cabang Palembang tetap mendapatkan perlindungan hukum jaminan secara umum sebagaimana diatur dalam Pasal 1131 dan Pasal 1132 KUH Perdata, hanya konsekuensi hukumnya PT. BFI Cabang Palembang berkedudukan sebagai kreditur konkuren yang tidak dijamin dengan suatu hak kebendaan tertentu dan tidak memiliki hak mengambil pelunasan terlebih dahulu dari kreditur lainnya. Hak jaminan yang bersifat umum ini dilahirkan atau timbul karena undang-undang, sehingga hak jaminan yang bersifat umum tidak perlu diperjanjikan sebelumnya. Ini berarti, kreditur konkuren secara bersamaan memperoleh hak jaminan yang bersifat umum dikarenakan oleh undangundang. ${ }^{20}$ Adapun isi kedua pasal di atas adalah sebagai berikut: Pasal 1131 KUH Perdata, bahwa: "Segala kebendaan si berutang, baik yang bergerak maupun yang tidak bergerak, baik yang sudah ada maupun yang baru akan ada di kemudian hari, menjadi tanggungan untuk segala perikatan perseorangan”. Kemudian dalam Pasal

20 Dilva Muzdaliva Sawotong, 2014, Jaminan Kebendaan ..., Op.Cit, hlm. 38.
1132 KUH Perdata dinyatakan: "Kebendaan tersebut menjadi jaminan bersama-sama bagi semua orang yang mengutangkan padanya; pendapatan penjualan benda-benda itu dibagi-bagi menurut keseimbangan, yaitu menurut besar kecilnya piutang masing-masing, kecuali apabila di antara para berpiutang itu ada alasan-alasan yang sah untuk didahulukan". ${ }^{21}$

\section{B. Perlindungan Hukum Pemilik Hak Atas Benda Akibat Penjaminan Fidusia secara Melawan Hukum.}

Jaminan Fidusia merupakan hak jaminan atas benda bergerak, baik benda berwujud maupun yang tidak berwujud dan benda tidak bergerak khususnya bangunan yang tidak dapat dibebani hak tanggungan sebagaimana dimaksud dalam Undang-Undang Nomor 4 Tahun 1996 Tentang Hak Tanggungan. Di dalam Kitab Undang Undang Hukum Perdata, ketentuan mengenai benda diatur dalam Buku II tentang Benda “Van Zaken”, Pasal 499 sampai dengan Pasal 1232. Benda menurut Pasal 499 KUH Perdata adalah: "Segala sesuatu yang dapat

21 Dilva Muzdaliva Sawotong, 2014, Jaminan Kebendaan ..., Ibid., hlm. 38. 
Anita Kamilah

Jurnal Hukum Mimbar Justitia

Vol. 4 No. 1 - Juni 2018

dihaki dan dapat dijadikan objek (eigendom) hak milik". ${ }^{22}$ Menurut sistem Hukum Perdata Barat sebagaimana diatur dalam KUH Perdata, benda dapat dibagi salah satunya adalah benda bergerak dan benda tidak bergerak. Kitab UndangUndang Hukum Perdata, memberikan hak kebendaan (zakelijkrecht) kepada pemilik benda atau barang tersebut, yaitu hak mutlak atas suatu benda dimana hak itu memberikan kekuasaan langsung atas sesuatu benda yang dapat dipertahankan terhadap siapapun juga dan setiap orang harus menghormatinya. Selain itu, hak kebendaan mempunyai ciri-ciri sebagai berikut:

a. Zaaksgevolg atau droit de suite, artinya hak itu terus mengikuti bendanya dimanapun dan dalam tangan siapapun juga barang itu berada;

b. Hak kebendaan memiliki hak terlebih dahulu (droit de preference);

c. Memiliki hak gugat kebendaan jika ada gangguan terhadap haknya yang berwujud :

22 Rindia Fanny Kusumaningtyas, 2016, Perkembangan Hukum Jaminan Fidusia... Op.Cit., hlm. 103.
Penuntutan kembali; (2) Gugatan untuk menghilangkan gangguan atas haknya; (3) Gugatan untuk pemulihan dalam keadaan semula; (4) Gugatan untuk penggantian kerugian dan sebagainya; dan

d. Kemungkinan untuk memindahkan hak kebendaan itu dapat dilakukan sepenuhnya. ${ }^{23}$

Di dalam Buku II KUH Perdata, diatur pula macam-macam hak kebendaan yaitu (1) Hak kebendaan yang memberikan kenikmatan (zakelijk genotsrechts), salah satu contohnya adalah hak milik; dan (2) Hak kebendaan yang memberikan jaminan (zakelijk zakerheidsrecht), seperti jaminan untuk benda bergerak yang dikenal dengan gadai dan fidusia, serta jaminan untuk benda tidak bergerak yaitu hipotek dan hak tanggungan. ${ }^{24}$

Dengan berlakunya UndangUndang No. 5 Tahun 1960 Tentang Peraturan Dasar Pokok-pokok Agraria, maka Buku II sepanjang mengenai bumi, air, dan kekayaan alam yang terkandung di dalamnya dicabut kecuali

\footnotetext{
23 Nur Adi Kumaladewi, 2015, Eksekusi Kendaraan Bermotor ..., Op.Cit., hlm. 64.

24 Dilva Muzdaliva Sawotong, 2014, Jaminan kebendaan ...., Op.Cit., hlm. 39.
} 
Anita Kamilah

Jurnal Hukum Mimbar Justitia

Vol. 4 No. 1 - Juni 2018

mengenai hipotek, dan sejak tahun 1996 hipotek sebagai jaminan atas tanah sudah tidak berlaku lagi dengan berlakunya Undang-Undang No. 4 Tahun 1996 Tentang Hak Tanggungan Atas Tanah dan Benda-benda Lain yang Berkaitan dengan Tanah. Sehubungan dengan hal tersebut, dalam membicarakan hak milik sebagai salah satu hak kebendaan adalah hak milik atas benda selain tanah, yang menurut Pasal 570 KUH Perdata bahwa :

"Hak milik adalah hak untuk menikmati kegunaan sesuatu kebendaan dengan leluasa dan untuk berbuat bebas terhadap kebendaan itu dengan kedaulatan sepenuhnya asal tidak bersalahan dengan undang-undang atau peraturan umum yang ditetapkan oleh suatu kekuasaan yang berhak menetapkannya dan tidak mengganggu hak-hak orang lain semua itu dengan tak mengurangi kemungkinan akan pencabutan hak itu demi kepentingan umum berdasar atas ketentuan undangundang dan dengan pembayaran ganti rugi".

Hak milik itu merupakan "droit inviolable et sacre", yaitu hak yang tidak dapat diganggu gugat yang ditujukan pada orang lain yang bukan eigenaar, walaupun dalam perkembangannya tidak lagi bersifat absolut karena adanya beberapa pembatasan seperti penggunaannya tidak boleh menimbulkan gangguan bagi orang lain dan tidak boleh menyalahgunakan hak (misbruik van recht). ${ }^{25}$ Hak milik sebagai salah satu hak kebendaan memiliki ciri-ciri sebagai berikut: (1) Merupakan hak induk terhadap hak kebendaan yang lain, sedangkan hak kebendaan lainnya yang bersifat terbatas itu berkedudukan sebagai anak hak milik itu; (2) Hak milik itu ditinjau secara kuantitetnya merupakan hak yang selengkaplengkapnya; (3) Hak milik itu tetap sifatnya, artinya tidak akan lenyap terhadap hak kebendaan lainnya, sedangkan hak kebedaaan lain akan lenyap menghadapi hak milik; (4) Hak milik sebagai hak kebendaan merupakan inti (benih) dari semua hak kebendaan lain, sedangkan hak kebendaan yang lain merupakan onderdeel (bagian) saja dari hak milik; dan (5) Hak untuk menuntut bendanya di pengadilan dari gangguan atau campur tangan pihak ketiga dalam hal hubungan hukum antara benda dengan pemiliknya. $^{26}$

25 Jaja S. Meliala, 2007, Perkembangan Hukum Perdata Tentang Benda Dan Hukum Perikatan, Nuansa Aulia, Bandung, hlm. 29.

26 Achmad Mu'in, 2015, Hak Pemegang Hak AtasTanah Eigendom Untuk Mendapatkan Hak Setelah Habisnya Waktu Sebagaimana 
Anita Kamilah

Jurnal Hukum Mimbar Justitia

Vol. 4 No. 1 - Juni 2018

Mengkaji pada konsep-konsep

hukum benda sebagaimana diuraikan di atas, maka Alimayer sebagai pemilik kendaraan yang hak kebendaannya mendapatkan gangguan karena dijadikan objek jaminan fidusia pihak lain tanpa seizin dan sepengetahuannya, memiliki dasar pijakan untuk menggunakan haknya melakukan gugat kebendaan yang berwujud pemulihan pemilikan kendaraannya dalam keadaan semula serta gugatan untuk penggantian kerugian yang gugatannya didasarkan pada ketentuan Pasal 1365 KUH Perdata tentang perbuatan melawan hukum (onrechtmatige daad), yang mewajibkan orang karena salahnya menerbitkan kerugian itu, mengganti kerugian tersebut". 27

Keberhasilan dalam melakukan tuntutan berdasarkan perbuatan melawan hukum sebagaimana diatur dalam Pasal 1365 KUH Perdata

Keputusan Presiden Republik Indonesia Nomor 32 Tahun 1979 Tentang Pokokpokok Kebijaksanaan Dalam Rangka Pemberian Hak Baru Atas Tanah Asal Konversi Hak-hak Barat, Calyptra Jurnal Ilmiah mahasiswa Universitas Surabaya, Volume. 4, No. 1, hlm. 7-8.

27 Velliana Tanaya, 2013, Rekonstruksi Asas Perbuatan Melawan Hukum (Onrechtmatige Daad) Dalam Gugatan Sengketa Konsumen, Asy-Syir'ah Jurnal Ilmu Syari'ah dan Hukum, Volume. 47, Nomor. 1, Juni, hlm. 310. menyaratkan untuk dapat membuktikan 4 (empat) hal, yaitu : ${ }^{28}$

1. Perbuatan yang melawan hukum.

Sebelum tahun 1919 pengertian perbuatan melawan hukum menganut ajaran legisme yang dikenal dengan ajaran sempit bahwa perbuatan melawan hukum hanya sekedar perbuatan yang melanggar hak subjektif orang lain atau yang bertentangan dengan kewajiban hukum dari sipembuat sendiri, yang telah diatur dalam undang-undang. Berlakunya Arrest Hoge Raad 31 Januari 1919 dalam perkara Lindenbaum vs Cohen, yang dikenal dengan "Drukkers Arrest", memberikan pengaruh yang cukup besar terhadap pengertian perbuatan melawan bahwa berbuat atau tidak berbuat merupakan suatu perbuatan melawan hukum apabila: (a) Melanggar hak subjektif orang lain; atau (b) Bertentangan dengan kewajiban hukum si pembuat; atau (c) Bertentangan dengan kesusilaan; atau (d) Bertentangan dengan ketentuan yang

28 Prihati Yuniarlin, 2012, Penerapan UnsurUnsur Perbuatan Melawan Hukum Terhadap Kreditur Yang Tidak Mendaftarkan Jaminan Fiducia, Jurnal Media Hukum, Volume. 19, Nomor. 1, Juni, hlm. 6-8. 
Anita Kamilah

Jurnal Hukum Mimbar Justitia

Vol. 4 No. 1 - Juni 2018

berlaku dalam lalu lintas masyarakat terhadap diri atau orang lain. ${ }^{29}$

Mengkaji pada syarat pertama, perbuatan Billy Warda Putra telah melanggar salah satu asas Nemoplus dalam Buku II KUH Perdata tentang Benda "Van Zaken", karena menjaminkan kendaraan milik orang lain tanpa seizin dan sepengetahuan pemiliknya sehingga merugikan serta melanggar hak kebendaan milik Alimajer, serta melanggar kepatutan dalam lalu lintas kehidupan bermasyarakat.

2. Harus ada kesalahan;

Syarat kesalahan dapat diukur secara objektif dan subjektif. Secara objektif harus dibuktikan bahwa dalam keadaan seperti itu manusia yang normal dapat menduga kemungkinan timbulnya akibat, dan kemungkinan ini akan mencegah manusia yang baik untuk berbuat atau tidak berbuat. Secara subjektif, harus diteliti apakah si pembuat berdasarkan keahlian yang

29 Agus Budi Susilo, 2013, Reformulasi Perbuatan Melanggar Hukum Oleh Badan Atau Pejabat Pemerintahan Dalam Konteks Kompetensi Absolut Peradilan Tata Usaha Negara, Jurnal Hukum dan Peradilan, Volume. 2, Nomor. 2, Juli, hlm. 294, dan Suharnoko, 2004, Hukum Perjanjian, Teori dan Analisa Hukum, Prenada, Jakarta, hlm. 119. dimilikinya dapat menduga akan akibat dari perbuatannya, serta orang yang melakukan perbuatan melawan hukum itu dapat dipertanggungjawabkan atas perbuatannya. $^{30}$

Kesalahan sebagaimana disyaratkan dalam Pasal 1365 KUH Perdata dapat dipenuhi, karena dari sudut pandang subjektif, Billy Warda Putra memiliki pemahaman bahwa menjaminkan barang orang lain tanpa seizin dan sepengetahuannya merupakan perbuatan yang melanggar hukum. Oleh karena itu, yang bersangkutan melakukan pemalsuan atas surat-surat kendaraan bermotor yang dipinjamnya seolah-olah kendaran tersebut miliknya yang telah dibeli dari Alimayer, sehingga dapat diterima sebagai objek jaminan fidusia oleh PT. BFI Cabang Palembang.

Dari sudut pandang objektif, setiap orang memiliki pandangan umum bahwa penjaminan kendaran milik Alimayer merupakan perbuatan melawan hukum yang merugikan pemilik kendaraan, karena jika Billy Warda Putra wanprestasi/lalai

30 Evalina Yessica, 2014, Karakteristik dan Kaitan Antara Perbuatan Melawan Hukum Dan Wanprestasi, Jurnal Refertorium, Volume. 1, Nomor. 2, November, hlm. 51. 
Anita Kamilah

Jurnal Hukum Mimbar Justitia

Vol. 4 No. 1 - Juni 2018

melunasi hutang sebagai perjanjian pokoknya, maka kendaraan sebagai objek jaminan fidusia tersebut akan digunakan untuk menjamin pelunasan hutang-hutangnya pada PT. BFI Cabang Palembang. Mengingat perbuatan yang dilakukannya dapat merugikan Alimayer sebagai pemilik kendaraan, seharusnya Billy Warda Putra memiliki kesadaran untuk tidak melakukan perbuatan melawan hukum tersebut.

3. Harus ada kerugian yang ditimbulkan.

Kerugian yang disebabkan perbuatan melawan hukum dapat berupa kerugian materiil yaitu kerugian yang nyata-nyata diderita dan keuntungan seharusnya diperoleh, serta kerugian idiil seperti ketakutan, sakit, kehilangan kesenangan hidup, dan ketidaknyamanan dalam pemakaian haknya. ${ }^{31}$

Mengkaji pada bentuk-bentuk kerugian tersebut, kerugian yang dialami Alimayer dapat berbentuk kerugian materiil maupun kerugian immaterial. Kerugian immateriil berupa terganggunya kenikmatan dalam

31 Evalina Yessica, 2014, Karakteristik dan Kaitan Antara Perbuatan Melawan Hukum ..., Ibid., hlm. 51. pemakaian barang atau kendaraannya karena tersangkut dengan penjaminan atas utang orang lain. Kerugian materiil, jika kendaraan yang dijadikan objek jaminan fidusia tersebut dilakukan penyitaan oleh PT. BFI Cabang Palembang untuk melunasi utang-utang Billy Warda Putra.

4. Ada hubungan causal antara perbuatan melawan hukum dan kerugian.

Ada dua teori guna mengetahui hubungan causal antara perbuatan melawan hukum dan kerugian, yaitu :

a. Teori Condition Sine Qua Non dari Von Buri, yang menyatakan:

"Suatu hal adalah sebab dari akibat, sedangkan suatu akibat tidak akan terjadi bila sebab itu tidak ada".

b. Teori Adequate Veroorzaking dari Van Kries, yang menyatakan: "Suatu hal adalah sebab dari suatu akibat bila menurut pengalaman masyarakat dapat diduga, bahwa sebab itu akan diikuti oleh akibat itu”.

Menelaah kembali syarat-syarat tuntutan perbuatan melawan hukum sebagaimana diatur dalam Pasal 1365 KUH Perdata, terakhir mengkaji dari 
Anita Kamilah

Jurnal Hukum Mimbar Justitia

Vol. 4 No. 1 - Juni 2018

salah satu teori di atas, yaitu Teori Adequate Veroorzaking, maka terdapat hubungan causal antara perbuatan melawan hukum dengan kerugian, dimana kerugian materiil maupun immateriil yang dialami Alimayer karena perbuatan melawan hukum yang dilakukan Billy Warda Putra, yang secara tidak patut dan melawan hukum menjaminkan kendaraan milik Alimayer sebagai objek jaminan fidusia. Pengalaman masyarakat secara umum sudah dapat menduga, jika Billy Warda Putra wanprestasi/lalai dalam melakukan pembayaran kepada PT. BFI Cabang Palembang, maka akibatnya sesuai Undang-Undang No. 42 Tahun 1999 Tentang Jaminan Fidusia kendaraan Alimayer akan dilakukan penyitaan untuk melunasi hutanghutang Billy Warda Putra kepada PT. BFI Cabang Palembang, sehingga merugikan Alimayer.

Ketentuan Pasal 1365 KUH Perdata tidak mengatur pemberian ganti rugi karena perbuatan melawan hukum, namun demikian sebagai bentuk perlindungan hukum terhadap Alimayer akibat perbuatan melawan hukum Billy Warda Putra dapat dilakukan tuntutan ganti rugi secara analogis sebagaimana diatur dalam KUH Perdata Pasal 1243 sampai Pasal $1252 .{ }^{32}$

Code Civil Perancis merinci ganti rugi dalam 2 (dua) unsur yaitu dommages dan interest. Dommages meliputi biaya serta rugi, dan interest sama dengan bunga yaitu keuntungan yang diharapkan atau yang sudah diperhitungkan akan diperoleh jika seandainya pihak debitur tidak lalai. Ganti rugi menurut Nieuwenheuis adalah membayar kerugian yang diderita oleh kreditur, dan Mariam Darus Badrulzaman mengartikan ganti rugi sebagai membayar kerugian yang nyata (feitelijknadee) yang dapat diperkirakan pada saat perikatan itu diadakan yang timbul sebagai akibat ingkar janji (wanprestasi). Dengan demikian, ganti rugi merupakan sanksi yang diberikan kreditur kepada debitur yang tidak memenuhi prestasinya berupa penggantian biaya, rugi, dan bunga. $^{33}$

32 Anita Kamilah, 2012, Bangun Guna Serah (Build Operate and Transfer/BOT) Membangun Tanpa Harus Memiliki Tanah (Perspektif Hukum Agraria, Hukum Perjanjian, dan Hukum Publik), Keni Media, Bandung, hlm. 79.

33 Dani Amalia Arifin, 2016, Kajian Yuridis Tanggung Jawab Perdata Rumah Sakit Akibat Kelalaian Dalam Pelayanan 
Anita Kamilah

Jurnal Hukum Mimbar Justitia

Vol. 4 No. 1 - Juni 2018

\section{Berdasarkan uraian di atas,}

Alimayer sebagai pihak yang dirugikan akibat penjaminan kendaraan sebagai objek jaminan fidusia yang pembebanannya dilakukan secara melawan hukum dapat menuntut ganti rugi sebagai berikut : (1) dapat berupa uang (dapat dengan uang pemaksa); (2) memulihkan dalam keadaan semula (dapat dengan uang pemaksa); larangan untuk tidak mengulangi perbuatan itu lagi (dapat dengan uang pemaksa); dan (4) dapat meminta putusan hakim bahwa perbuatannya adalah bersifat melawan hukum. ${ }^{34}$

Namun demikian, kerugian yang dapat dituntut oleh pihak yang dirugikan jumlahnya tidak dapat diperhitungkan dengan sekehendak hatinya, tetapi sesuai dengan doktrin hubungan sebab akibat sebagaimana diatur dalam Pasal 1247 KUH Perdata, penuntutan ganti ruginya hanya dapat diberikan yang mempunyai hubungan sebab akibat secara langsung dari wanprestasi atau perbuatan melawan hukum yang

Kesehatan, Jurnal Idea Hukum, Volume. 2, Nomor. 1, Maret, hlm. 86.

34 Trisadini Prasastinah Usanti, 2012, Lahirnya Hak Kebendaan, Jurnal PERSPEKTIF, Volume. 17, Nomor. 1, Januari, hIm. 46. dilakukannya. $^{35}$ Selain itu, guna menentukan luasnya kerugian yang harus diganti umumnya didasarkan pada suatu prinsip bahwa yang dirugikan harus sedapat mungkin ditempatkan dalam keadaan seperti keadaan jika tidak terjadi perbuatan melawan hukum.

\section{PENUTUP}

A. Kesimpulan

1. Keabsahan Sertifikat Jaminan Fidusia Atas Barang Milik Pihak Ketiga Yang Penjaminannya Dilakukan Secara Melawan Hukum.

Jaminan fidusia yang 37 pembebanannya dilakukan dengan melanggar Pasal $1320 \mathrm{KUH}$ Perdata serta melanggar ketentuan Pasal 1365 KUH Perdata tentang perbuatan melawan hukum (Onrechtmatige daad) berakibat tidak sahnya sertifikat jaminan fidusia. Ketidakabsahan sertifikat jaminan fidusia, merujuk ketentuan Pasal 1444 sampai dengan Pasal 1456 KUH Perdata akibat hukumnya pihak kreditur tidak memiliki sifat mendahului

35 Anita Kamilah, 2012, Bangun Guna Serah (Build Operate and Transfer/BOT) ..., Op.Cit., hlm. 81. 
Anita Kamilah

Jurnal Hukum Mimbar Justitia

Vol. 4 No. 1 - Juni 2018

(preferent) untuk dilakukan pembayaran utang-utangnya jika debitur wanprestasi atau lalai. Namun demikian, kreditur tetap mendapat perlindungan hukum sebagai kreditur konkuren yang memperoleh hak jaminan yang bersifat umum yang dilahirkan oleh undang-undang sebagaimana diatur dalam Pasal 1131 dan Pasal 1132 KUH Perdata.

2. Perlindungan Hukum Pemilik Hak Atas Benda Akibat Penjaminan Fidusia secara

\section{Melawan Hukum.}

Jaminan fidusia merupakan salah satu hak kebendaan yang memberi jaminan, sehingga memiliki keterkaitan dengan hukum benda sebagaimana diatur dalam Buku II KUH Perdata tentang Benda "Van Zaken", Pasal 499 sampai dengan Pasal 1232. Hukum benda adalah hukum yang mengatur hubungan hukum seseorang dengan benda, dimana salah satunya adalah hak milik sebagai objek jaminan fidusia. Hak milik sebagaimana diatur dalam Pasal $570 \mathrm{KUH}$ Perdata merupakan salah satu hak kebendaan yang memiliki ciri akan mengikuti bendanya dalam tangan siapapun benda itu berada, sehingga

memberikan kewenangan kepada pemilik benda tersebut untuk menguasai benda itu dalam tangan siapapun benda itu berada, dan setiap orang harus menghormatinya. Oleh karena itu, jika ada seseorang secara melawan hukum menjaminkan kebendaan miliknya tanpa seizin dan sepengetahuannya kemudian menyebabkan kerugian atas kepemilikannya, dapat melakukan tuntutan berdasarkan perbuatan

melawan hukum sebagaimana diatur dalam Pasal $1365 \mathrm{KUH}$ Perdata serta melakukan tuntutan ganti rugi sebagaimana diatur dalam KUH Perdata Pasal 1243 sampai Pasal 1252, yang bentuk tuntutannya dapat berupa : (1) Uang (dapat dengan uang pemaksa); (2) memulihkan dalam keadaan semula (dapat dengan uang pemaksa); (3) larangan untuk tidak mengulangi perbuatan itu lagi (dapat dengan uang pemaksa); dan (4) dapat meminta putusan hakim bahwa 
perbuatannya adalah bersifat melawan hukum.

\section{B. Saran}

1. Alimayer sebagai pihak yang dirugikan Billy Warda Putra akibat penjaminan kendaraan miliknya sebagai objek fidusia yang dilakukan tanpa seizin dan sepengetahuannya, dapat menggunakan hak untuk melakukan pembatalan sertifikat fidusia melalui ketentuan Pasal 1365 KUH Perdata tentang perbuatan melawan hukum disertai dengan penuntutan ganti rugi.

2. Guna menghindari terjadinya penjaminan milik orang lain secara melawan hukum, hendaknya PT. BFI Cabang Palembang memiliki kehati-hatian dengan melakukan pengecekan secara langsung baik terhadap barangnya maupun kepemilikan dari bendanya.

3. Guna memberikan perlindungan terhadap PT. BFI Cabang Palembang yang sertifikat fidusianya dilakukan pembatalan karena tidak sahnya objek fidusia yang dijadikan jaminan, perusahaan dapat meminta Billy Warda Putra untuk melakukan penjaminan kembali atas benda yang lain, sehingga PT. BFI Cabang Palembang memiliki kedudukan preferent jika Billy Warda Putra wanprestasi dalam melakukan pembayaran kredit.

\section{DAFTAR ISI}

\section{A. Buku}

Agus Yudha Hernoko, 2010, Hukum Perjanjian : Asas Proporsionalitas dalam Kontrak Komersial, Kencana Prenada Media Group, Jakarta.

Anita Kamilah, 2012, Bangun Guna Serah (Build Operate and Transfer/BOT) Membangun Tanpa Harus Memiliki Tanah (Perspektif Hukum Agraria, Hukum Perjanjian, dan Hukum Publik), Keni Media, Bandung.

Jaja S. Meliala, 2007, Perkembangan Hukum Perdata Tentang Benda Dan Hukum Perikatan, Nuansa Aulia, Bandung.

Ronny Hanitijo Soemitro, 1990, Metodologi Penelitian Hukum Dan Jurimetri, Ghalia Indonesia, Jakarta.

Syamsul Anwar, 2007, Hukum Perjanjian Syariah, Grafindo Persada, Jakarta. 
Suharnoko, 2004, Hukum Perjanjian, Teori dan Analisa Hukum, Prenada, Jakarta.

Muhamad Djumhana, 2008, Asas-Asas Hukum Perbankan, Citra Aditya Bakti, Bandung.

Munir Fuady, 2013, Perbuatan Melawan Hukum Pendekatan Kontemporer, Citra Aditya Bakti, Bandung.

\section{B. Peraturan Perundang- Undangan}

Undang-Undang Dasar 1945.

Kitab Undang-Undang Hukum Perdata.

Undang-Undang No. 5 Tahun 1960 Tentang Peraturan Dasar Pokokpokok Agraria.

Undang-Undang No. 4 Tahun 1996 Tentang Hak Tanggungan Atas Tanah dan Benda-benda Lain yang Berkaitan dengan Tanah.

Undang-Undang No. 7 Tahun 1992, sebagaimana telah diubah oleh Undang-Undang No. 10 Tahun 1998 Tentang Perbankan.

Undang-Undang No. 42 Tahun 1999 Tentang Jaminan Fidusia.

\section{Jurnal, Makalah, Internet dan} Lain-lain.

Atik Indriyani, 2006, Aspek Hukum Personal Guaranty, Jurnal Hukum PRIORIS, Volume 1, Nomor 1, Edisi September.

Achmad Mu'in, 2015, Hak Pemegang Hak AtasTanah Eigendom Untuk Mendapatkan Hak
Setelah Habisnya Waktu Sebagaimana Keputusan Presiden Republik Indonesia Nomor 32 Tahun 1979 Tentang Pokok-pokok Kebijaksanaan Dalam Rangka Pemberian Hak Baru Atas Tanah Asal Konversi Hak-hak Barat, Calyptra Jurnal Ilmiah mahasiswa Universitas Surabaya, Volume 4, No. 1.

Agus Budi Susilo, 2013, Reformulasi Perbuatan Melanggar Hukum Oleh Badan Atau Pejabat Pemerintahan Dalam Konteks Kompetensi Absolut Peradilan Tata Usaha Negara, Jurnal Hukum dan Peradilan, Volume 2, Nomor 2, Edisi Juli.

Clara Lina Amanda Sumeisey, 2014, Eksekusi Benda Jaminan Yang Dibebani Hak Tanggungan Ketika Debitur Pailit, Jurnal Lex et Societatis, Volume II, No.9, Edisi Desember.

Dilva Muzdaliva Sawotong, 2014, Jaminan Kebendaan Pada PT. Pegadaian Terhadap Barang Yang Digadaikan, Jurnal Lex Privatum, Volume II, No. 1, Edisi Januari-Maret.

Debora R.N.N. Manurung, 2015, Perlindungan Hukum Debitur Terhadap Parate Eksekusi Obyek Jaminan Fidusia, Jurnal Ilmu Hukum Legal Opinion, Volume 3, No. 2.

Dian Pertiwi, 2012, Perlindungan Pemegang Hak Tanggungan Yang Objeknya Dikuasai Pihak Ketiga Berdasarkan Perjanjian 


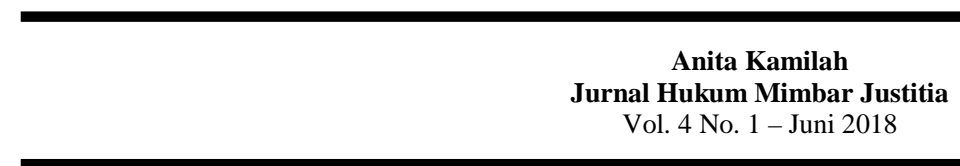

Sewa Menyewa, Caliptra Jurnal Ilmiah Mahasiswa Universitas Surabaya, Volume 19, No. 1, Edisi Juni.

Dani Amalia Arifin, 2016, Kajian Yuridis Tanggung Jawab Perdata Rumah Sakit Akibat Kelalaian Dalam Pelayanan Kesehatan, Jurnal Idea Hukum, Volume 2, No. 1, Edisi Maret.

Evalina Yessica, 2014, Karakteristik dan Kaitan Antara Perbuatan Melawan Hukum Dan Wanprestasi, Jurnal Refertorium, Volume 1, No. 2, Edisi November.

Ficky Nento, 2016, Tinjauan Hukum Hapusnya Perikatan Jual Beli Barang Menurut Kitab Undang-Undang Hukum Perdata, Jurnal Lex Crimen, Volume V, No. 6, Edisi Agustus.

Miftah Idris, 2015, Perjanjian Kredit Perbankan Konvensional Dan Akad Pembiayaan Perbankan Syariah: Suatu Tinjauan Deskriptif Dalam Hukum Di Indonesia, Jurnal Komunikasi Hukum, Volume 1, Nomor 1, Edisi Pebruari.

Muhamad Rizky Djangkarang, 2013, Aspek Hukum Pengalihan Hak Tagihan Melalui Cessie, Jurnal Lex Privatum, Volume 1, No. 5, Edisi November.

Muladi, 2009, Pentingnya Lembaga Jaminan Fidusia Dalam Meningkatkan Pembangunan Ekonomi Nasional, Makalah
Seminar

Nasional

Problematika

Dalam

Pelaksanaan Jaminan Fidusia di Indonesia : Upaya Menuju Kepastian Hukum, Fakultas Hukum Universitas Semarang, Semarang.

Nur Adi Kumaladewi, 2015, Eksekusi Kendaraan Bermotor Sebagai Jaminan Fidusia yang Berada Pada Pihak Ketiga, Jurnal Repertorium, Volume II, No. 2, Edisi Juli - Desember.

Nur Amin Solikhah, 2015, Problematika Hukum UndangUndang No. 42 Tahun 1999 Tentang Jaminan Fidusia Terkait Dengan Peraturan Menteri Keuangan Republik Indonesia No. 130/PMK.010/2012, Jurnal Repertorium, Edisi 3, Edisi Januari - Juni.

Prihati Yuniarlin, 2012, Penerapan Unsur-unsur Perbuatan Melawan Hukum Terhadap Kreditur Yang Tidak Mendaftarkan Jaminan Fiducia, Jurnal Media Hukum, Volume 19, No. 1, Edisi Juni.

Rindia Fanny Kusumaningtyas, 2016, Perkembangan Hukum Jaminan Fidusia Berkaitan dengan Hak Cipta Sebagai Objek Jaminan Fidusia, Jurnal Pandecta, Volume 11, Nomor 1, Edisi Juni.

Trisadini Prasastinah Usanti, 2012, Lahirnya Hak Kebendaan, Jurnal PERSPEKTIF, Volume XVII, No. 1, Edisi Januari. 
Velliana Tanaya, 2013, Rekonstruksi Asas Perbuatan Melawan Hukum (Onrechtmatige Daad) Dalam Gugatan Sengketa Konsumen, Asy-Syir'ah Jurnal Ilmu Syari'ah dan Hukum, Volume 47, No. 1, Edisi Juni.

Winda Pebrianti, 2012, Tinjauan Hukum Atas Eksekusi Obyek Jaminan Fidusia Melalui Parate Eksekusi Apabila Obyek Jaminan Beralih Kepada Pihak Ketiga atau Musnah, Jurnal Supremasi Hukum, Volume 21, No. 1, Edisi Januari.

Laporan Hasil Penyelidikan Kepolisian Negara Repubik Indonesia Daerah Sumatera Selatan Direktorat Reserse Kriminal Khusus No. LHP/XII/2016/Subdit

II/Ditreskrimus, Desember 2016. 